\title{
Sprawozdanie z wyjazdu naukowego studentów Wydziału Prawa Kanonicznego Uniwersytetu Papieskiego Jana Pawła II w Krakowie do Rzymu w dniach 17-24 maja 2016 roku \\ DOI: http://dx.doi.org/10.15633/acan.1833
}

Coroczną tradycją obowiązującą na Wydziale Prawa Kanonicznego Uniwersytetu Papieskiego Jana II w Krakowie jest wyjazd naukowy studentów trzeciego roku do Rzymu w celu uzyskania praktycznej wiedzy na temat funkcjonowania dykasterii Kurii Rzymskiej. W dniach 17 do 24 maja 2016 roku studenci wraz ze swoim opiekunem naukowym - prodziekanem Wydziału Prawa Kanonicznego ks. dr. Andrzejem Sosnowskim cR odbyli taki wyjazd, dzięki któremu mieli możliwość zapoznania się z funkcjonowaniem wybranych instytucji kościelnych, w szczególności trybunałów apostolskich (Najwyższego Trybunału Sygnatury Apostolskiej, Trybunału Roty Rzymskiej) oraz wybranych kongregacji (Kongregacji Nauki Wiary, Kongregacji Spraw Kanonizacyjnych). Dodatkowo odwiedzili Papieski Uniwersytet Gregoriański, w którym funkcjonuje Wydział Prawa Kanonicznego, oraz Ambasadę Rzeczypospolitej Polskiej przy Stolicy Apostolskiej.

Dnia 18 maja studenci udali się na plac Świętego Piotra, aby uczestniczyć w generalnej audiencji ojca świętego Franciszka. Papież w swojej katechezie odwoływał się do przypowieści o bogaczu i ubogim Łazarzu (Łk 16, 19-31), których życie biegło po równoległych torach, jednakże ich warunki życiowe były wzajemnie sprzeczne. Ojciec święty podkreślił, że Łazarz, którego imię oznacza „Bóg pomaga”, reprezentuje milczące wołanie ubogich wszystkich czasów i sprzeczność świata, w którym ogromne bogactwo i zasoby znajdują się w rękach nielicznych osób. W przypowieści bogacz nie ma imienia, podczas gdy imię ubogiego powtarzane jest pięciokrotnie. Łazarz leżący u bramy jest dla bogacza żywym przypomnieniem, by pamiętać o Bogu. Będzie potępiony nie za swoje bogactwo, lecz za to, że nie potrafił odczuć współczucia dla Łazarza i pospieszyć mu na ratunek. W życiu przyszłym sytuacja się odwróciła: aniołowie zanieśli Łazarza na łono Abrahama, natomiast bogacz został strącony do piekła. Papież Franciszek zwrócił uwagę, że bogacz znał słowo Boże, ale go nie słuchał, bo nie potrafił otworzyć oczu i ulitować się nad ubogim. W opisanym przez przypowieść odwróceniu losów ukryta jest tajemnica naszego zbawienia, w którym Chrystus jednoczy ubóstwo $\mathrm{z}$ miłosierdziem. 
Pierwszym z zaplanowanych na 19 maja spotkań była wizyta w Najwyższym Trybunale Sygnatury Apostolskiej, którego siedziba znajduje się w Palazzo della Cancelleria. Przybyłych powitał w języku łacińskim sekretarz NTSA abp Frans Daneels opraem z Belgi, który powiedział, że „prawnik, który nie zna łaciny, jest jak egzegeta Pisma Świętego, który nie zna języka hebrajskiego”. Podczas spotkania ksiądz prałat dr Paweł Malecha, pełniący urząd zastępcy promotora sprawiedliwości, odniósł się do wykładów gościnnych prowadzonych na Wydziale Prawa Kanonicznego UPJPII w dniach 11-12 maja 2016 roku, przypominając trzy sekcje działające w ramach NTSA (sprawy sądowe, administracyjne i comissio pontificia) oraz problematykę rekursu sporno-administracyjnego wnoszonego do NTSA (przedmiot, legitymacja procesowa do wniesienia, terminy i sposób wniesienia, opłaty).

Co roku sądy kościelne z całego świata przesyłają do NTSA sprawozdania dotyczące liczby pracowników trybunału, liczby rozpatrywanych spraw (w przypadku spraw o stwierdzenie nieważności małżeństwa - częstotliwości tytułów nieważności). Dane te są gromadzone w corocznie wydawanym roczniku statystycznym. Wskutek wejścia w życie 8 grudnia 2015 roku motu proprio papieża Franciszka Mitis Iudex Dominus Iesus z 15 sierpnia 2015 roku, reformującego kanony kodeksu prawa kanonicznego dotyczące spraw o stwierdzenie nieważności małżeństwa, powstała potrzeba zmiany formularza wysyłanego do NTSA.

Studenci mieli możliwość przyjrzenia się jeszcze niezatwierdzonemu projektowi nowego formularza, który będzie obowiązywał od 2017 roku. Na jego pierwszej stronie będą się znajdować dane dotyczące sądu kościelnego, czyli nazwa (w języku własnym i łacińskim) oraz adres, numer telefonu, faksu i adres poczty elektronicznej. Na kolejnej stronie będzie można zawrzeć dodatkowe informacje. Na stronie trzeciej i czwartej będą odnotowywane dane pracowników trybunału i adwokatów (imię i nazwisko, data urodzenia, w przypadku osób duchownych - posiadane święcenia, stopnie naukowe, dyspensa do wykonywania funkcji sędziego do czasu uzyskania stosownych uprawnień obejmująca dzień, kiedy została przyznana dyspensa i informację, na jak długo została przyznana). Na kolejnej stronie formularza będą poruszane kwestie dotyczące skarg powodowych wnoszonych do trybunału (ile zostało wniesionych, ile zostało przyjętych, a ile odrzuconych; ile zostało przyjętych do procesu zwyczajnego, ile do procesu skróconego, a ile do procesu dokumentalnego). Ksiądz prałat Malecha zwrócił uwagę, że tego typu dane pozwalają zrozumieć, jak funkcjonuje trybunał, gdyż np. w Polsce pojawia się niebezpieczna tendencja odrzucenia skarg powodowych już 
na etapie przedprocesowym, tj. podczas dyżuru w poradni prawnej funkcjonującej przy trybunale, wskazując stronie brak podstaw do stwierdzenia nieważności małżeństwa, a tego typu działanie stanowi naruszenie prawa do procesu. Następnie w formularzu będą wymagane dane dotyczące procesu zwyczajnego (ile spraw na początku roku nadal się toczy, ile zostało przyjętych, a ile przekazanych do procesu skróconego), jakie były wyroki, z jakich tytułów nieważności sprawy się toczyły, liczba zaskarżonych wyroków przez obrońcę węzła małżeńskiego oraz liczba spraw będących w toku na końcu roku, dzięki czemu będzie można zweryfikować funkcjonowanie trybunału w ciągu roku. Szósta strona formularza będzie poświęcona sprawom dotyczącym procesu skróconego (będą podawane te same informacje, co przy procesie zwyczajnym), a siódma - sprawom dotyczącym nieważności, toczącym się w procesie skróconym w przypadku trybunałów międzydiecezjalnych. Strona ósma będzie przeznaczona na sprawy toczące się w ramach procesu dokumentalnego, a następna - na kwestie dotyczące aktywności trybunałów drugiej instancji (ile spraw na początku roku, a ile na końcu, ile jest apelacji od procesu zwyczajnego, a ile od skróconego).

Na bazie tych informacji NTSA sporządza dane, które wskazuję liczbę toczących się spraw w poszczególnych państwach ${ }^{1}$. Przykładowo w Polsce na początku 1997 roku toczyło się 3185 spraw, w 2003 roku - 4576, w 2007 roku - 6804, a na początku 2015 roku około 13 ooo spraw. Wzrost w Polsce liczby spraw dotyczących stwierdzenia nieważności małżeństwa spowodowany jest wzrostem liczby spraw dotyczących rozwiązania małżeństwa przez rozwód, toczących się przed sądem państwowym. We Włoszech państwo uznaje sentencje wydawane przez trybunały kościelne w zakresie stwierdzenia nieważności małżeństwa, zaś w praktyce łatwiej uzyskać stwierdzenie nieważności małżeństwa w trybunale kościelnym aniżeli w sądzie włoskim.

Dodatkowo ks. Malecha przybliżył słuchaczom statystyki z 2012 roku dotyczące liczby wydanych wyroków pozytywnych w poszczególnych polskich trybunałach kościelnych. Przykładowo w Katowicach było to 72 proc., Krakowie 64 proc., Opolu 86 proc., Lublinie 95 proc., Siedlcach 99 proc., Poznaniu 68 proc. czy Warszawie 96 procent. Ogółem w Polsce w 2012 roku wydano 79,3 proc. pozytywnych

\footnotetext{
$1 \quad$ Ksiądz prałat Paweł Malecha wskazał, że tego typu dane można znaleźć również w publikacji naukowej wydanej pod redakcją ks. prof. Tomasza Rozkruta zatytułowanej IV. Ogólnopolskie Forum Sądowe: „Orzecznictwo rotalne w praktyce sq̨dowej Kościoła”. Materiaty z ogólnopolskiego spotkania pracowników sq̨downictwa kościelnego w Gródku nad Dunajcem w dniach 15-16 czerwca 2009 roku, Tarnów 2010, s. 11-49.
} 
wyroków stwierdzających nieważność małżeństwa. Natomiast w poszczególnych państwach świata statystyki kształtowały się następująco: w Hiszpanii 86 proc., Francji 93 proc., Irlandii 91 proc., Kanadzie 99,5 proc., Niemczech 82 proc., Ukrainie 95 proc., Węgrzech 87 proc., Wielkiej Brytanii 88 proc., Włoszech 86 proc., Stanach Zjednoczonych 96 procent.

Drugim spotkaniem, które odbyło się tego dnia, była wizyta w Ambasadzie Rzeczypospolitej Polskiej przy Stolicy Apostolskiej i spotkanie z ambasadorem Je dr. Piotrem Nowiną-Konopką. Studenci mieli okazję wystuchać historii polskiej ambasady przy Stolicy Apostolskiej, dowiedzieć się, jakie są zadania i obowiązki ambasadora wynikające z ustawy z dnia 27 lipca 2001 r. o służbie zagranicznej oraz jakie są aktualne działania podejmowane przez ambasadę służące zaciśleniu współpracy międzynarodowej między Rzeczpospolitą Polską a Stolicą Apostolską. Pan ambasador z zainteresowaniem przysłuchiwał się wypowiedziom studentów na temat celu przyjazdu do Rzymu, po czym wręczył każdemu zaproszenie na spotkanie poświęcone pamięci abp. Józefa Życińskiego (1948-2011) - arcybiskupa metropolity lubelskiego, wielkiego kanclerza Katolickiego Uniwersytetu Lubelskiego Jana Pawła II w Lublinie, zorganizowane przez ambasadę we współpracy z kard. Gianfranco Ravasim przewodniczącym Papieskiej Rady Kultury, które miało się odbyć dnia 23 maja 2016 roku. Wizyta w ambasadzie zakończyła drugi aktywny dzień studenckiego wyjazdu naukowego.

Następnego dnia, tj. 20 maja, studenci po raz kolejny udali się do Palazzo della Cancelleria, tym razem w celu zwiedzenia Trybunału Roty Rzymskiej. Spotkaniu przewodniczył ksiądz prałat dr Robert Gołębiowski pełniący urząd obrońcy węzła małżeńskiego, który na wstępie opowiedział historię Palazzo della Cancelleria, będącego najlepszym przykładem włoskiego renesansu. Nazwa jest nieprzypadkowa, gdyż miała tu siedzibę Kancelaria Państwa Kościelnego. Budynek został zbudowany przez kard. Raffaele Riaria, syna siostrzenicy papieża Sykstusa IV, do którego realizacji (w latach 1483-1517) przyczyniło się kilku architektów, takich jak Baccio Pontelli, Andrea Bregno i Donato Bramante. Kolumny zostały ściągnięte z Koloseum i z pałacu senatora Pompejusza na Largo di Torre Argentina, w miejscu gdzie został zamordowany Juliusz Cezar. Aktualnie pałac jest siedzibą czterech ważnych dykasterii Stolicy Apostolskiej - Penitencjarii Apostolskiej (pierwsze piętro), Najwyższego Trybunału Sygnatury Apostolskiej (drugie piętro), Trybunału Roty Rzymskiej (pierwsze i drugie piętro) oraz Instytutu Archeologicznego Stolicy Apostolskiej. 
Na pierwszym piętrze pałacu znajdują się sale przeznaczone dla studentów Studium Rotalnego działającego przy Rocie Rzymskiej, mającego na celu pogłębienie znajomości orzecznictwa tego Trybunału Apostolskiego. Pierwszy rok Studium Rotalnego jest poświęcony symulacjom, drugi - sprawom iurium, a trzeci - niezdolności psychicznej. Obecnie trwają prace nad rozpoczęciem zajęć w formie „e-learningu” dla kanonistów z całego świata. Ksiądz prałat Gołębiowski, będący absolwentem Studium Rotalnego, przybliżył studentom, jak wygląda egzamin końcowy $^{2}$. Adwokaci Stolicy Apostolskiej są wybierani spośród adwokatów rotalnych, którym są powierzane sprawy o wyższym stopniu skomplikowania.

Trybunał Roty Rzymskiej gromadzi zbiory prawa kanonicznego, cywilnego z XVII i XVIII wieku, w tym oryginalne wyroki, jakie wydała Rota od 1908 roku aż do teraz. Natomiast akta spraw nigdy nie są niszczone, lecz podlegają archiwizacji.

Studenci mieli możliwość zwiedzenia archiwum Roty Rzymskiej posiadające do własnego użytku najnowocześniejszy system komputerowy Intranet, służący do digitalizacji akt wszystkich spraw napływających do Roty Rzymskiej. Do kompetencji dziekana Roty Rzymskiej należy ustalanie turnusów. Do każdej sprawy przydzielonych jest trzech sędziów. Aktualnie w Trybunale Roty Rzymskiej rozpatrywanych jest 740 bieżących spraw, z czego część dotyczy Kościołów wschodnich (sprawy małżeńskie, w których rozstrzygane są również skutki cywilne małżeństwa ${ }^{3}$ ). Podczas zwiedzania Trybunału Roty Rzymskiej studenci mieli możliwość poznania ks. dr. Tomasza Kubiczka - pierwszego notariusza, który przedstawił zadania pierwszego oraz drugiego notariusza ${ }^{4}$.

2 Aby przystąpić do egzaminu końcowego, trzeba posiadać stopień doktora nauk prawnych z zakresu prawa kanonicznego. Egzamin końcowy rozpoczyna się o godz. 9 i trwa do godz. 21. Rozpoczyna go dziekan Roty Rzymskiej, który otwiera kopertę i określa, co studenci mają przygotować w języku łacińskim - przykładowo wyrok na określony tytuł nieważności. Prace sprawdza dwóch sędziów rotalnych. Osoba, która nie otrzymała wyniku pozytywnego, może ponownie podejść do egzaminu za rok, natomiast jeżeli po raz drugi otrzymała ocenę negatywną, to już nie może zostać adwokatem rotalnym, chyba że otrzyma specjalne pozwolenie od ojca świętego.

3 Na podstawie umów międzynarodowych zleca się trybunałom kościelnym rozstrzyganie spraw dotyczących skutków cywilnych (np. alimenty), które następnie są uznawane na gruncie państwowym. Wskutek wejścia w życie Mitis Iudex Dominus Iesus Trybunał Roty Rzymskiej po otrzymaniu apelacji zleca rozstrzyganie tego typu spraw ukonstytuowanemu trybunałowi apelacyjnemu, na terenie państwa, w którym został wydany zaskarżony wyrok. Sprawy dotyczące skutków cywilnych nie mogą być rozstrzygane $w$ formie dekretu, lecz jedynie w wyroku.

4 Do kompetencji pierwszego notariusza Trybunału Roty Rzymskiej należy odbieranie wszelkich pism, wniosków czy dokumentów; rejestracja wszystkich decyzji wydawanych w Rocie, które wpisywane 
Na sam koniec spotkania ksiądz prałat Gołębiowski przedstawił aktualne problemy powstałe z momentem wejścia w życie Mitis Iudex Dominus Iesus w zakresie postępowania apelacyjnego. Kanon $168 \mathrm{o} \S 1 \mathrm{w}$ nowym brzmieniu przewiduje prawo do wniesienia apelacji. Z kolei w $§ 2$ stanowi nowość w kanonicznym prawie procesowym, gdyż przewiduje możliwość odrzucenia apelacji w sytuacji uznania, że ma na celu działanie na zwłokę, następnie wydania dekretu potwierdzającego wyrok pierwszej instancji. W tym miejscu Trybunał Roty Rzymskiej rozpatrywał kwestię, czy wydanie w procesie zwyczajnym w pierwszej instancji wyroku negatywnego można potwierdzić w formie dekretu. Uznano, że nie, bo regulacja dotyczy wyłącznie wyroku afirmatywnego (pozytywnego), a nie negatywnego. Drugi problem, jaki się pojawia, to kwestia zastosowania Mitis Iudex Dominus Iesus w sytuacji wydania przez trybunał pierwszej instancji wyroku pozytywnego, zaś w drugiej instancji - negatywnego. Łacińskie tłumaczenie kan. 1680 § 2 mówi o sententiam prioris, a dokonując analizy tłumaczenia powyższej frazy na różne języki, można zwrócić uwagę, że część krajów błędnie przetłumaczyła to jako „pierwsza instancja” (Włochy, Francja), a prawidłowe brzmienie to „poprzednia instancja" (Polska, Niemcy).

Drugim wydarzeniem, które odbyło się tego dnia, była wizyta w Papieskim Uniwersytecie Gregoriańskim. Spotkaniu przewodniczył o. prof. Janusz Kowal sJ, który przedstawił historię uniwersytetu założonego w 1551 roku przez św. Ignacego Loyolę. W 1584 roku nastąpiło znacjonalizowanie dóbr kościelnych, stąd też papież Grzegorz XıII erygował nową siedzibę uczelni, stając się jednocześnie jej opiekunem. Studia licencjackie z zakresu prawa kanonicznego do 2001 roku trwały dwa lata, natomiast po reformie wydłużono je do trzech lat. Ojciec prof. Kowal podkreślił, że nie można studiować prawa kanonicznego w sposób ścisły, z pominięciem historii oraz teologii. Corocznie od października do maja na Wydziale Prawa Kanonicznego organizowany jest kurs jurysprudencji orzecznictwa rotalnego prowadzony w formie seminarium na temat poszczególnych tytułów nieważności małżeństwa. Na każdych zajęciach studenci otrzymują akta sprawy i dostają czas na przygotowanie wyroku czy animadversiones obrońcy węzła małżeńskiego,

\footnotetext{
są do księgi. Trybunał Roty Rzymskiej prowadzi rejestry od czasu wydania przez papieża Piusa X konstytucji Sapienti consilio przeprowadzającej reformę Kurii Rzymskiej, tj. od 1908 roku. Z kolei do zadań drugiego notariusza należy komunikacja „ze światem” poprzez prowadzenie wymiany korespondencji drogą pocztową zwykłą, jak i elektroniczną oraz notyfikacja dekretów sędziów w danej sprawie.
} 
następnie prace zostają oceniane przez profesora. Krakowscy studenci mieli okazję zobaczyć bibliotekę uniwersytecką, gdzie znajduje się ponad sześć tysięcy czasopism oraz zgromadzone są bieżące oryginalne wyroki Trybunału Roty Rzymskiej, dzięki którym można studiować orzecznictwo rotalne podczas seminariów naukowych.

Przedostatni dzień pobytu w Rzymie studenci WPK rozpoczęli od wizyty w Kongregacji Nauki Wiary, której patronem jest papież Pius V. Spotkaniu przewodniczył ksiądz prałat dr Albert Warso. Na wstępie przedstawił on historię Kongregacji powołanej przez papieża Pawła III 21 lipca 1542 roku5, która z początku rozstrzygała kwestie, co jest schizmą, herezją, a co prawdziwą wiarą. Niedługo później papież Paweł IV poszerzył kompetencje Kongregacji o sprawy odnoszące się do moralności. W 1588 roku papież Sykstus V zarezerwował Kongregacji wszystkie sprawy odnoszące się do wiary i moralności. Z kolei w 1566 roku papież Pius V dołączył jej sprawy dotyczące indeksu ksiąg zakazanych. W 1908 roku papież Pius X zmienił nazwę tej instytucji na „Kongregacja Świętego Oficjum”. Kongregacja ta później zyskała miano suprema - najważniejszej spośród wszystkich dykasterii rzymskich - na jej czele stał papież. Papież Benedykt XV w 1917 roku włączył do kompetencji Kongregacji indeks ksiąg zakazanych, a kwestie dotyczące odpustów zostały przekazane Penitencjarii Apostolskiej. Papież Paweł vi 7 grudnia 1965 roku zmienił nazwę Kongregacji na „Święta Kongregacja Nauki Wiary”, i zarazem wyznaczył jej następujące cele: promocja wiary, strzeżenie depozytu wiary. Po wejściu w życie kodeksu prawa kanonicznego z 1983 roku papież Jan Paweł II w konstytucji apostolskiej Pastor bonus z 28 czerwca 1988 roku dokonał reformy Kurii Rzymskiej oraz zmienił jej nazwę na „Kongregacja Nauki Wiary".

Na czele Kongregacji stoi prefekt kardynał, który wykonuje zadania za pomocą sekretarza, sekretarza pomocniczego, podsekretarza, grupy ekspertów teologów z całego świata (konsultorów) ${ }^{6}$. Członkami rzeczywistymi Kongregacji są kardynałowie oraz biskupi ${ }^{7}$, których jest około dwudziestu. W Kongre-

5 Inaczej nazywana Świętą Kongregacją Inkwizycji Rzymskiej i Powszechnej, Kongregacją Świętej Inkwizycji lub Inkwizycją Rzymską.

6 Liczba konsultorów wynosi około dwudziestu osób, z czego jeden jest Polakiem i jest nim o. Wojciech Giertych OP.

7 Wśród Polaków członkami Kongregacji są abp Stanisław Kornecki oraz abp Stanisław Gądecki przewodniczący Konferencji Episkopatu Polski. 
gacji są cztery departamenty: doktrynalny, dyscyplinarny, małżeński oraz archiwum $^{8}$.

Studenci mieli możliwość zwiedzenia muzeum funkcjonującego w ramach Kongregacji, w którym znajduje się bulla papieska nadająca przywileje Kongregacji Świętego Oficjum, XVIII-wieczna księga procesów, oryginalny Katechizm Kościoła katolickiego podpisany przez papieża Jana Pawła II, rzeczy związane z objawieniami prywatnymi (dziennik z zapisanymi objawieniami; hostia, która miała być uznana za cudowną, płaczące rzeźby, figurki, ampułki z krwią) czy prośby o ogłoszenie dogmatu o wniebowzięciu Matki Najświętszej. Z kolei w archiwum studenci mogli przejrzeć ostatnie wydanie indeksu ksiąg zakazanych wydanego w 1948 roku oraz sześć tomów Pisma Świętego z 1658 roku przekazanego na indeks ksiąg zakazanych ze względu na osobę tłumacza, który był anglikaninem.

Drugim wydarzeniem tego dnia była wizyta w Kongregacji Spraw Kanonizacyjnych i spotkanie z jej podsekretarzem księdzem prałatem dr Bogusławem Turkiem CSMA, który - podobnie jak podczas wykładów gościnnych na Wydziale Prawa Kanonicznego UPJPII w dniach 15-16 maja 2014 roku - przybliżył studentom zadania oraz historię Kongregacji. Początki procesów kanonizacyjnych sięgają przełomu XI i XII wieku, kiedy lud oddawał cześć zarówno męczennikom, jak i osobom mało znanym, przez co dochodziło do szeregu nadużyć. Stąd też papież Aleksander III zakazał publicznego oddawania czci bez jego zgody. Następnie za pontyfikatu papieża Sykstusa V utworzono Kongregację do spraw Świętych Obrzędów (1588 rok), której zadaniem było zajmowanie się liturgią, ceremoniałami i sprawami kanonizacyjnymi. Z kolei Benedykt XIV w dziele De servorum Dei beatificatione

8 Urząd doktrynalny bada, strzeże i promuje kwestie wiary. Odpowiada również na pytania płynące ze świata. Wiele dokumentów, które są ogłaszane przez konferencje episkopatów, musi uzyskać wcześniejsze zatwierdzenie przez Stolicę Apostolską.

Urząd dyscyplinarny zajmuje się szeroko pojmowanymi zagadnieniami dyscyplinarnymi oraz dotyczącymi objawień. Na mocy motu proprio Jana Pawła II Sacramentorum sanctitatis tutela z 2001 roku ze zmianami wprowadzonymi przez papieża Benedykta XVI w 2010 roku, dla Kongregacji Nauki Wiary zostały zastrzeżone niektóre przestępstwa tzw. gravioribus delictis, w stosunku do których Kongregacja jest „Najwyższym Trybunałem Apostolskim”. Nazwa jest zaczerpnięta z konstytucji apostolskiej Pastor bonus. Kongregacja otrzymała również kompetencję do autoryzowania biskupów do prowadzenia procesów karnych administracyjnych w przestępstwach zarezerwowanych dla Stolicy Apostolskiej. Dla tego urzędu są też zarezerwowane kwestie domniemanych objawień, cudów.

Urząd małżeński zajmuje się kwestią przywileju Pawłowego dotyczącego rozwiązania małżeństwa na korzyść wiary (in favorem fldei).

Archiwum posiada zbiory dokumentów sporządzone od początku funkcjonowania Kongregacji, zgromadzone są w nim także akta procesowe inkwizycyjne. 
et beatorum canonizatione przedstawił procedurę kanonizacyjną stanowiącą zarazem punkt odniesienia w rozwiązywaniu przypadków nietypowych. Papież Paweł vi 8 maja 1969 roku podzielił Kongregację na Kongregację Kultu Bożego i Dyscypliny Sakramentów oraz Kongregację Spraw Kanonizacyjnych.

Ksiądz prałat Turek oprowadził zebranych po archiwum, w którym znajdują się wszystkie dekrety wydane przez Kongregację od 1588 roku do dzisiaj. Są dwie serie dekretów - pierwsze to dekrety liturgiczne, a drugie to dekrety dotyczące spraw beatyfikacyjnych i kanonizacyjnych. Zgromadzono również wszelkie dokumenty, na podstawie których zostały wydane decyzje. W czasie zwiedzania archiwum studenci mieli możliwość zobaczenia kilku oryginalnych dokumentów związanych z procesami beatyfikacyjnymi, w szczególności list Michała Radziwiłła, sporządzony na skórze i wysłany do Kongregacji w związku z beatyfikacją św. Stanisława Kostki, listy króla Jana Kazimierza, bulle papieskie dotyczące św. Jacka, list króla Zygmunta III Wazy sporządzony na skórze czy listy króla Jana III Sobieskiego. Kongregacja posiada pozycje drukowane od 1814 roku, a wcześniejsze znajdują się w bibliotece narodowej w Paryżu, ponieważ w 1810 roku Napoleon wywiózł wszelkie archiwa watykańskie do stolicy. Dopiero w 1814 roku zwrócono Kongregacji część zgrabionych dokumentów, przede wszystkim manuskrypty.

Tego samego dnia część studentów w odpowiedzi na zaproszenie ambasadora Piotra Nowiny-Konopki wzięło udział w spotkaniu poświęconym pamięci abp. Józefa Życińskiego, podczas którego wspominano go jako człowieka wiary, kultury, filozofii, nauki, komunikacji oraz społecznego dialogu. Na spotkanie przybył prymas Polski abp Wojciech Polak, który wraz z Przewodniczącym Papieskiej Rady Kultury kard. Gianfranco Ravasim wspominał abp. Życińskiego jako człowieka inspirującego młodych biskupów, uczącego tak jak papież Franciszek, że Kościół musi realizować styl Wieczernika, gdyż w momencie wyjścia z Wieczernika rodzi się Kościól. Następnie o. Tomasz Dostatni op oraz prof. Gaspare Mura skupili się na przedstawieniu abp. Życińskiego przez pryzmat jego filozoficznych i kosmologicznych przemyśleń, wypowiedzi wielokrotnie odwołujących się do przemówień św. Jana Pawła II do Papieskiej Akademii Nauk na temat ewolucjonizmu. Prócz tego przedmiotem zainteresowań arcybiskupa był fundamentalizm i postmodernizm. Ksiądz prof. Rafael Martinez i ks. prof. Alfred Wierzbicki wymienili cechy charakterystyczne dominujące u abp. Życińskiego, do których należały serdeczność, bliskość czy głęboka duchowość. Rozwijał teologię człowieka nauczaną przez papieża Jana Pawła II, wskazując, że posiadamy ją dzięki rozumowi oraz wiedzy. Zaczynał jako scjentysta, a skończył na filozofii kultury. Pani redaktor Aleksandra 
Klich przybliżyła portret arcyciskupa jako człowieka komunikacji: należał on do osób błyskotliwych, a zarazem skromnych, niebojących się poruszać trudne tematy, w szczególności dyskutując na tematy polityczne, które zgodnie z arystotelesowskim rozumieniem miały kierować się dobrem ogółu. Z kolei deputowany Rocco Buttiglione i redaktor Zbigniew Nosowski przypomnieli, że -zdaniem arcybiskupa - prawda na pewno nie leży pośrodku. Arcybiskup Życiński wielokrotnie podkreślał, jak duże znaczenie ma nauka, dzięki której człowiek może poznać kosmos. Na samym końcu zabrał głos ks. Tomasz Adamczyk - sekretarz osobisty abp. Życińskiego, ukazując go jako człowieka wrażliwego na biedę, ponieważ pochodził z ubogiej rodziny, stającego w obronie ludzi, którym działa się krzywda. Miał magnetyczną osobowość, gdyż należał do osób inteligentnych i przenikliwych. W swoich wypowiedziach wielokrotnie odwoływał się do Sokratesa.

Możliwość wyjazdu do Rzymu w celu zapoznania się z praktycznym funkcjonowaniem wybranych dykasterii Kurii Rzymskiej, które są bardzo dobrze znane studentom pod względem teoretycznym, pozostaje niezwykle cennym doświadczeniem dla przyszłych młodych kanonistów. Spotkania z pracownikami instytucji kościelnych czy ośrodków naukowych, w których kształcą się przyszli kanoniści, pozwalają uzyskać studentom wiedzę praktyczną w zakresie stosowania prawa kanonicznego, zwłaszcza po wejściu w życie Mitis Iudex Dominus Iesus wprowadzającej gruntowną zmianę w kanonicznym prawie procesowym.

Karolina Mazur 